\title{
Progress in Slovak botany: a successful path to modern research on flora and vegetation
}

\author{
Pavol Eliáš Jr ${ }^{1}$ (D) Katarína Hegedüšová Vantarová ${ }^{2}$ (D) \\ Received: 2 June 2021 / Accepted: 3 June 2021 / Published online: 15 June 2021 \\ (C) Plant Science and Biodiversity Centre, Slovak Academy of Sciences 2021
}

\begin{abstract}
Here, we present a brief introduction to sixteen full-text research articles of the Special Issue "Progress in Slovak Botany: a successful path to modern research on flora and vegetation" which are more-less a reflection of the current state of the study of botany in Slovakia. The papers bring results of classification and syntaxonomical revision of shrubs and forest vegetation, followed by research into vegetation diversity, ecology, and taxonomy. Special attention is paid to molecular methods in the research of plant taxa; one of the contributions evaluates the use of these methods in the study of population genetics of forest trees in Slovakia in the past 40 years. The other three papers use the knowledge of flow cytometry for a taxonomic study of selected representatives of the genera Tanacetum, Cotoneaster, Solanum and Nicotiana. A special issue also includes a new version of the checklist and a red list of hornworts and liverworts which updates data published 20 years ago. The checklist is followed by a paper on new localities and phylogenetic relationships of Leucoglossum leucosporum, a geoglossoid fungus whose occurrence is poorly known. The last two contributions are devoted to the impact of the environmental burdens on biota.
\end{abstract}

Keywords Classification $\cdot$ Diversity $\cdot$ Ecology $\cdot$ Fungi $\cdot$ Plant communities $\cdot$ Phytotoxicity $\cdot$ Slovakia $\cdot$ Syntaxonomical revision $\cdot$ Taxonomy

\section{Introduction}

Botanical research in the territory of present-day Slovakia has a long tradition until the end of the sixteenth century. Manuscript medical-botanical and fruit-horticultural works of anonymous authors from this period have been preserved (Jurkovič 1970; Hrabovec 1979), as well as the first scientific study on the vegetation of the Pannonian region prepared by the French botanist Carolus Clusius was published in 1583 (Hrabovec 1974). The oldest herbarium created by the Kamaldul monk Cyprián has been preserved from the middle of the eighteenth century (Vozárová 1996).

Pavol Eliáš, Jr

pavol.elias.jun@gmail.com

Katarína Hegedüšová Vantarová

katarina.hegedusova@savba.sk

1 Department of Environment and Biology, Slovak University of Agriculture in Nitra, A. Hlinku 2, 94976 Nitra, Slovak Republic

2 Institute of Botany, Department of Geobotany, Plant Science and Biodiversity Center, Slovak Academy of Sciences, Dúbravská cesta 9, 84523 Bratislava, Slovak Republic
While in the 17th and 18th centuries botanists of Austrian and Hungarian origin took part in botanical research in the territory of present-day Slovakia, from the nineteenth century, works by authors of Slovak origin began to be promoted and published (Dionýz Štúr, Andrej Kmet', Jozef L'udovít Holuby). Thanks to G. Reuss, one of the first more comprehensive regional flora in Hungary, "Května Slovenska = Flora of Slovakia" (Reuss 1853), was created. After the disintegration of the Austro-Hungarian Empire in connection with the First World War and the establishment of Czechoslovakia, Czech botanists became significantly involved in research (Hendrych 1996), because Hungarian and Austrian botanists mostly engaged in research outside of present-day Slovakia or left.

A long-term problem was the absence of a science-oriented university institution enabling the education of new generations of naturalists, including botanists. In the past, only a few educational institutions of the university type operated on the territory of today's Slovakia, several only temporarily, such as Trnava University in the years 1635-1777 (moved to Budapest) (Jankovič 1995) or Universitas Cassoviensis in Košice founded in 1657 (Mártonfiová et al. 2021). The Mining and Forestry Academy in Banská Štiavnica, founded 
in 1763 and moved to Sopron (SW Hungary) in 1919 (Konečný 2012), has been operating here for the longest time. Thus, most botanists working in present-day Slovakia received their education most often in Vienna, Prague, or Budapest. A significant turnaround took place in the late 1940s on the threshold of World War II. After the break-up of Czechoslovakia by the Nazis, the establishment of the first Slovak Republic (1939-1945) and the closure of Czech universities, there was an acute need to provide education in the natural sciences directly in Slovakia. In October 1939, the Institute of Botany was established within the Faculty of Arts of the Slovak University (renamed Comenius University during the war), led by the Czech botanist František Nábělek, and the following year the Faculty of Science was established. Among its important graduates were Ján Futák, one of the most important figures in Slovak postwar botany, the author of the first botanical monograph in modern Slovak (Futák 1943), and one of the first employees of the Institute of Botany of the Slovak Academy of Sciences founded in 1952 (Letz 2016). There is also a further development of science-oriented higher education, the University of Pavel Jozef Šafárik in Košice was founded as the second university in Slovakia in 1959.

Applied botanical disciplines such as agriculture and forestry were also developed, the Department of Forestry and Agricultural Engineering was established at the Slovak University of Technology in Bratislava and teaching began in 1941. From this department, Colleague of Agricultural and Forestry Engineering was founded in 1946 in Košice. Later, in 1952, as part of the reorganization of universities, this colleague was divided into two separate universities - the current Slovak University of Agriculture in Nitra and the Technical University in Zvolen providing education in the field of forestry and woodworking.

At present, in addition to the Institute of Botany of the Slovak Academy of Sciences, attention is being paid to scientific research in the field of botany at seven Slovak universities. We present the results of their work in this special issue.

\section{The main contribution of the presented studies}

The classification and syntaxonomical revision of vegetation are essential tools for scientific communication. In addition, they provide a reliable platform for land-use management and nature conservation. In Slovakia, it has a long tradition (Holub et al. 1967; Valachovič 1995; Valachovič 2001; Jarolímek et al. 1997; Kliment and Valachovič 2007; Hegedüšová Vantarová and Škodová 2014).

In the presented Special Issue, two of the studies provide insight into the classification of common hazel scrub (Kliment et al. 2021) and beech forests (Ujházyová et al. 2021). In Slovakia, common hazel-dominated stands represent a typical landscape component of colline to montane areas. Out of five associations previously reported from Slovakia (Jurko 1964; Passarge 1979; Kontriš 1981; Hadač and Terray 1989) two of them, Pruno spinosae-Coryletum and Lonicero nigraeCoryletum within one alliance Populo tremulae-Corylion avellanae, were accepted based on the syntaxonomical revision. Moreover, the authors compared West Carpathian communities with relevant Alpine and Hercynian ones and identified the climatic gradient as the main environmental drivers of the floristic composition of the hazel-dominated vegetation in Slovakia.

In Europe, the classification of beech, fir and mixed montane forests has already been unified at the rank of alliance and higher syntaxa in Europe by several authors (Dierschke 1998; Willner 2002; Willner and Grabherr 2007; Mucina et al. 2016; Willner et al. 2017). A complete syntaxonomical revision of these forest communities within the order Fagetalia sylvaticae was realised for the first time in Slovakia by Ujházyová et al. (2021). Finally, 18 associations were accepted within the alliances Fagion sylvaticae, Symphyto cordati-Fagion, Lonicero alpigenae-Fagion and Sorbo-Fagion. There were applied the concept of narrow orders and alliances (Mucina et al. 2016) in accordance with the actual concept of the Slovak national survey of forest communities.

Recently, much attention is paid on diversity and ecology of the alien species. According to Denisow et al. (2017), Jehlík et al. (2017), Vinogradova et al. (2017), Májeková et al. (2021) synanthropic plants connected with human activity find suitable conditions also on railway. On the other hand, some native thermophilous species, rare and threatened plants (Novinska and Czarna 2008; Májeková et al. 2014; Jasprica et al. 2017; Vinogradova et al. 2017) typical for other habitats are also occurred here. The authors present four species (Euphorbia davidii, Galeopsis angustifolia, Geranium purpureum, Grindelia squarrosa) that are typical examples of ferroviatic migration either in Slovakia or Ukraine.

The impact of global climate change on vegetation has become increasingly prominent over the past several decades. Understanding vegetation change and its response to climate can provide fundamental information for environmental resource management (Sun et al. 2021). Gradual climate warming has a crucial impact on alpine vegetation where tall grasses together with phanerophytes expand (Hedenås et al. 2016; Vanneste et al. 2017). Climate changes along with landuse change, mainly grazing cessation, inspired Palaj and Kollár (2021) to study this question in the Tatra Mts. They confirmed increased frequency of phanerophytes, mainly Pinus mugo, lesser Juniperus communis and Picea abies. The most susceptible communities to the expansion of phanerophytes are Juncion trifidi grasslands and dwarf shrub communities dominated by ericaceous species. Moreover, the grasslands facing phanerophyte expansion are more lightdemanding than others and phanerophytes significantly affect the light and temperature conditions on the sites. In 
conclusion, the area of grasslands was reduced by more than $22 \%$ and simultaneously there is a visible transformation from grasslands into tree and shrub vegetation.

Climatic changes are also responsible for the decline of critically endangered species Cladium mariscus on Žitný ostrov Island (Procházka et al. 2021). In Slovakia, and several other European countries it has a rare occurrence (Feráková et al. 2001; Eliáš et al. 2003). The authors present analytic results of sedimentary-infilling from the locality where the occurrence of Cladium mariscus was reported in a palaeoecological sample radiocarbon-dated to $9.52 \mathrm{cal} \mathrm{ka} \mathrm{BP}$ in the Early Holocene. The species persistence is depending on its sensitivity to changes in a hydrological regime which is often affected by anthropogenic activity (Theocharopoulos et al. 2006; Plóciennik et al. 2015; Gałka et al. 2017).

Another species that is dependent on the hydrological and nutrient regime is Calla palustris (Dudgeon et al. 2006; Richert et al. 2016). Its distribution, ecology and vegetation affinity are discussed in the article by Dudáš et al. (2021). After critical revision of all available phytosociological and herbarium material, the authors find that vulnerable Cala palustris the most frequently occurs in the vegetation of mires (classes Scheuchzerio-Caricetea fuscae, OxycoccoSphagnetea, Vaccinio-Piceetea), alder carrs (Alnetea glutinosae class), and marshes (Phragmito-Magnocaricetea class) of the northern parts of Slovakia (the Nízke Beskydy Mts, Spišské vrchy Mts and Liptovská kotlina Basin) which are protected at national or international levels and included into Ramsar localities, NATURA 2000 sites, protected landscape areas, national parks or nature reserves.

One from important and rare wetland habitats are periodically exposed banks of stagnant water. As a result of water regulation in the past, these natural habitats mainly with vegetation of the class Isoëeto-Nanojuncetea in Slovakia and the surrounding Central European countries have recently become scattered. In the current Special Issue, Dítě et al. (2021) provide insight into the vegetation on the shores of the Liptovská Mara water reservoir four decades after its construction. Even though, the water reservoirs vegetation have been relatively well documented in Slovakia (e.g. Jarolímek et al. 1997, 1999; Bernátová and Kučera 2010; Šumberová and Hrivnák 2013; Kochjarová et al. 2015), the data on Liptovská Mara water reservoir have not been published to date. The analysis of 52 phytosociological relevés identified three clearly distinct vegetation groups, 1. BidentiPolygonetum hydropiperis and Rumici crispi-Agrostietum stoloniferae, 2. Junco bufonii-Gnaphalietum uliginosi, 3. Eleocharito acicularis-Limoselletum aquaticae. Authors found that the main ecological factors responsible for the zonation of plant communities are the length of flooding, slope and soil texture. Despite the secondary origin of the study object, the species composition is natural, and the spreading of neophytes was not detected.
Molecular methods of speciation and phylogeny study of plant taxa are among the most important methods today. Relatively soon after their discovery, they began to be used in former Czechoslovakia, namely in the eighties (Kormuták 1981; Kormuták et al. 1982). One of the presented papers summarizes the development of population genetics and population genomics studies of forest trees in Slovakia during the past 40 years (Gömöry et al. 2021). To address several topics in evolutionary genetics and biogeography of trees, various protein and DNA markers have been applied during this period: allozymes uniparentally inherited chloroplast and mitochondrial markers, simple sequence repeats and single nucleotide polymorphisms. As a model species, Fagus sylvatica s. 1. and eastern-Mediterranean firs (Abies Mill. section Abies) were selected and the divergence of genetic lineages (species and subspecific taxa) in time, as well as colonization of the current ranges during the Holocene were reconstructed. Intraspecific gene flow and homoploid hybridization focused on hybrid swarms Pinus sylvestris/P. mugo and firs were also studied (Kormuták et al. 2005, 2008). Adaptations were studied both in field observations and common-garden experiments on Picea abies, F. sylvatica and A. alba (Longauer et al. 2001; Gömöry et al. 2015). Within this contribution, next-generation sequencing perspectives of ongoing research were shortly outlined, too (Gömöry et al. 2021).

Flow cytometry - another powerful method in molecular biology that provides rapid multi-parametric analysis of single cells in solution (McKinnon 2018) has been used in three papers included in this special issue, which deals with selected representatives of the genera Tanacetum (Pulišová et al. 2021), Cotoneaster (Kšiňan et al. 2021), Solanum and Nicotiana (Fráková et al. 2021).

Pulišová et al. (2021) presented a comprehensive overview of the karyological and morphological variability of the Tanacetum corymbosum group in Slovakia. Flow cytometry analyses confirmed two predominant cytotypes within T. corymbosum group in Slovakia: diploids corresponding to T. clusii and tetraploids corresponding to $T$. corymbosum. A rare occurrence of minority cytotypes (triploids and pentaploids), as well as the occurrence of single triploid plant most probably of hybrid origin, was found. Morphological analyses showed that the number and size of stem leaves as well as capitula, and coloration of the margin of the involucral bracts were identified as the most useful for their determination. Based on this research, the authors recommend recognizing $T$. clusii and $T$. corymbosum as two separate species rather than subspecies.

Genome size analysed by flow cytometry is reliable diagnostic tool in the determination of closely related genera included in Rosaceae family (Hajrudinović et al. 2015; Macková et al. 2017; Žabka et al. 2018). Kšiňan et al. (2021) try to find out, whether it is possible to distinguish close related Cotoneaster species based on the absolute genome size data. Flow cytometry revealed a significant difference in genome size between 
pentaploid C. tomentosus and both tetraploid species C. integerrimus and C. melanocarpus agg. However, they found that the identification of tetraploid species $C$. integerrimus and C. melanocarpus agg. Based on nuclear DNA content is not possible.

Endopolyploidy plays a vital role during plant growth and development and in various stress responses (Ceccarelli et al. 2006). To better understand and characterise polysomatic species within the Solanaceae, Fráková et al. (2021) studied endopolyploidy in mature vegetative and reproductive organs of representative diploids within the genus Capsicum and diploid and tetraploids within the genus Nicotiana using flow cytometry. The presence of $2 \mathrm{C}-16 \mathrm{C}$ nuclei (rarely $32 \mathrm{C}$ ) was detected in both genera, and the degree of endopolyploidisation was expressed using four different parameters for each organ analysed. Furthermore, genome size for each of the investigated species was determined in this study.

Checklists incorporate progress in plant taxonomy and nomenclature as possible and provide a taxonomic and nomenclatural basis for botanical studies, species surveys in nature conservation and vegetation and floristic databases (Danihelka et al. 2012). A global trend of permanent extinction of species or decline of their populations caused by human activity has led to the emergence of red lists of endangered species (Turis et al. 2014; Eliás et al. 2015). The last checklist and the red list of liverworts (Marchantiophyta) and hornworts (Anthocerotophyta) were published 20 years ago in Slovakia (Kubinská et al. 2001a, 2001b) and did not correspond to current knowledge about this group of plants. Therefore, the revised checklist and red list of hornworts and liverworts were prepared by Mišíková et al. (2021) following the latest version of the Checklist of mosses (Bryophyta) (Mišíková et al. 2020). The presented checklist and red list include 231 liverwort and two hornwort species, with up to $22.9 \%$ liverworts are endangered species. Hornworts are not considered threatened.

Central Europe is a region with long study history of geoglossoid fungi, e. g. they are mentioned at the end of the eighteenth century from the territory of today's Slovakia (Lumnitzer 1791). Within this group, the small and poorly studied genus Leucoglossum is included. Kučera et al. (2021) recently recorded L. leucosporum in Germany, the Czech Republic, and Slovakia, reports from the Czech Republic and Slovakia representing the first data to those countries. Molecular phylogenetic analyse confirmed a separate position of the genus, which is more closely related to Geoglossum rather than Trichoglossum despite the presence of setae.

Heavily destroyed landscape in post-industrial areas is dominated mostly by anthropogenic vegetation (KompałaBaba et al. 2019). Mine abandonment, decommissioning and repurposing may result in significant environmental impacts, such as soil and water contamination (Haddaway et al. 2019). Orchidaceae are an endangered group of plants that might spontaneously grow also in the anthropogenic environment on initial soils (e.g. Woch 2017, 2018; Woch et al. 2016, 2018). Račko et al. (2021) investigated the influence of heavy metals on the populations of the orchids Epipactis atrorubens, E. pontica, Cephalanthera longifolia and Platanthera bifolia on three localities with different soil conditions and various composition of toxic elements. The authors found that elevated concentration of heavy metals and toxic elements in plant tissues is closely related to the occurrence and weathering of original contaminated substrates. Despite the high concentration of heavy metals and toxic elements in old mining sites orchids are able to adapt to these specific conditions.

Nosalj et al. (2021) evaluated the effect of remediation on three plots at the site Banská Štiavnica - Šobov (the Štiavnické vrchy Mts, central Slovakia) where a heap of mining residues was established in the past and remediation was done 20 years ago. Measurements of basic chemical properties at the study area confirmed ongoing acidification, with an effect on soil properties. Acidification of the soil environment is also reflected in the composition of microscopic filamentous fungi, Penicillium species predominated and Zygomycota species were randomly present. The structure of microfungal communities was directly influenced by soil reaction $(\mathrm{pH})$ and closely linked to the soil type.

The last contribution of the special issue is also devoted to the impact of the environmental burden on the biota, specifically the possible transfer of antimony from abandoned antimony mines to the bodies of Macromycetes and higher plants (Kautmanová et al. 2021). The study showed the consumption of edible mushrooms and medicinal plants from the studied localities represents a risk of intoxication for humans. The highest values of arsenic and cadmium were recorded in Agaricus arvensis, Suillus accumulated high levels of mercury, antimony and chromium. The species Cardamine amara is considered as a hyperaccumulator of all tested elements because it is characterized by the highest values of all species. On the other hand, these species can be used for phytoremediation of contaminated sites.

Acknowledgments First of all, we would like to thank all authors who contributed to this Special Issue of Biologia "Progress in Slovak Botany". We are also grateful to our Editor, Milan Valachovič, and Reviewers for their detailed insight into the manuscripts and helpful comments. Our special thanks are given to the Springer team for their work on the papers before publishing.

During the Special Issue preparation, Katarína Hegedüšová was funded by VEGA 2/0132/21 grant and Pavol Eliáš was funded by VEGA 1/0047/19 grant.

\section{References}

Bernátová D, Kučera P (2010) Rastlinné spoločenstvo Eleocharito acicularis-Limoselletum aquaticae vo Vel'kej Fatre [Plant community Eleocharito acicularis-Limoselletum aquaticae in the Vel'ká Fatra Mts]. Zborn Orav Múz 27:260-265 
Ceccarelli M, Santantonio E, Marmottini F, Amzallag GN, Cionini PG (2006) Chromosome endoreduplication as a factor of salt adaptation in Sorghum bicolor. Protoplasma 227:113-118. https://doi.org/10. 1007/s00709-005-0144-0

Danihelka J, Chrtek J Jr, Kaplan Z (2012) Checklist of vascular plants of the Czech Republic. Preslia 84:647-811

Denisow B, Wrzesień M, Mamchur Z, Chuba M (2017) Invasive flora within urban railway areas: a case study from Lublin (Poland) and Lviv (Ukraine). Acta Agrobot 70:1727

Dierschke H (1998) Syntaxomomical survey of European beech forests: some general conclusions. Ann Bot 55(1997):17-26. https://doi.org/ 10.4462/annbotrm-9030

Dítě D, Šuvada R, Dítě Z (2021) Seasonal dynamics of a periodically flooded man-made habitat in a submontane region: Junco bufoniiGnaphalietum uliginosi or Cyperetum micheliani? Biologia 76(7)

Dudáš M, Slezák M, Hrivnák R (2021) Distribution, ecology and vegetation affinity of bog arum (Calla palustris) in Slovakia. Biologia 76(7)

Dudgeon D, Arthington AH, Gessner MO, Kawabata Z-I, Knowler DJ, Lévêque C, Naiman RJ, Prieur-Richard A-H, Soto D, StiassnyMLJ SCA (2006) Freshwater biodiversity: importance, threats, status and conservation challenges. Biol Rev 81:163-182. https://doi.org/10. 1017/S1464793105006950

Eliáš P Jr, Dítě D, Kliment J, Hrivnák R, Feráková V (2015) Red list of ferns and flowering plants of Slovakia, 5th edition (October 2014). Biologia 70:218-228. https://doi.org/10.1515/biolog-2015-0018

Eliáš P, Dítě D, Sádovský M (2003) Poznámky k výskytu Cladium mariscus (L.) Pohl na Slovensku [Comments to the Cladium mariscus L. Pohl occurrence in Slovakia]. Bull Slov Bot Spoločn 25:109-114

Fráková V, Koprivý L, Palová M, Kolarčik V, Mártonfi P (2021) Evaluation of endopolyploidy patterns in selected Capsicum and Nicotiana species (Solanaceae). Biologia 76(7)

Feráková V, Maglocký Š, Marhold K (2001) Červený zoznam paprad'orastov a semenných rastlín Slovenska [Red list of ferns and seed plants]. Ochr Prír 20:44-77

Futák J (1943) Kremnické hory. Štúdia geobotanicko-floristická [Kremnické hory Mts. A Geobotanical-floristic study]. Matica slovenská, Turčiansky sv. Martin

Gałka M, Aunina L, Feurdean A, Hutchinson S, Kołaczek P, Apolinarska K (2017) Rich fen development in CE Europe, resilience to climate change and human impact over the last ca. 3500 years. Palaeogeogr Palaeocl 473:57-72. https://doi.org/10.1016/j.palaeo.2017.02.030

Gömöry D, Ditmarová L', Hrivnák M, Jamnická G, Kmet' J, Krajmerová D, Kurjak D (2015) Differentiation in phenological and physiological traits in European beech (Fagus sylvatica L.). Eur J For Res 134: 1075-1085. https://doi.org/10.1007/s10342-015-0910-2

Gömöry D, Krajmerová D, Hrivnák M, Longauer R, Schmidtová J (2021) From allozymes to NGS: population genetics of forest trees in Slovakia in the past 40 years. Biologia 76(7)

Hadač E, Terray J (1989) Wood plant communities of the Bukovské vrchy hills, NE Slovakia. Folia Geobot Phytotax 24:337-370

Haddaway NR, Cooke SJ, Lesser P, Biljana Macura B, Nilsson AE, Taylor JJ, Raito K (2019) Evidence of the impacts of metal mining and the effectiveness of mining mitigation measures on socialecological systems in Arctic and boreal regions: a systematic map protocol. Environ Evid:8/9. https://doi.org/10.1186/s13750-0190152-8

Hajrudinović A, Siljak-Yakovlev S, Brown SC, Pustahija F, Bourge M, Ballian D, Bogunić F (2015) When sexual meets apomict: genome size, ploidy level and reproductive mode variation of Sorbus aria s.1. and S. austriaca (Rosaceae) in Bosnia and Herzegovina. Ann Bot 116:301-312. https://doi.org/10.1093/aob/mcv093

Hedenås H, Christensen P, Svensson J (2016) Changes in vegetation cover and composition in the Swedish mountain region. Environ
Monit Assess 188(8):452. https://doi.org/10.1007/s10661-016$5457-2$

Hegedüšová Vantarová K, Škodová I (eds) (2014) Rastlinné spoločenstvá Slovenska 5. Travinno-bylinná vegetácia [Plant communities of Slovakia 5. Grassland vegetation]. Bratislava, Veda

Hendrych R (1996) Podíl české botaniky na výzkumu Slovenska a jeho souvislosti [The role of Czech botany in the research of Slovakia and its context]. Zprávy Čes Bot Společ 31:85-100

Holub J, Hejný S, Moravec J, Neuhaüsl R (1967) Übersicht der höheren Vegetationseinheiten der Tschechoslowakei. - Rozpr Českoslov Akad Věd, Ser. Math.-Natur 77/3: 1-75

Hrabovec I (1974) Botanik Charles de l'Ecluse - Carolus Clusius. Biologia 29:87-91

Hrabovec I (1979) Ohlas a vplyv Matioliho diela na Slovensku [Response and influence of Mattioli's work in Slovakia]. Práce Ďejin Př́r Věd 12:89-193

Jankovič V (1995) Trnavská univerzita: kapitoly o dejinách univerzity v rokoch 1635-1777 [Trnava University: chapters on the history of the university in the years 1635-1777]. Pamiatkový ústav, Bratislava

Jarolímek I, Zaliberová M, Mucina L, Mochnacký S (1997) Rastlinné spoločenstvá Slovenska. 2. Synantropná vegetácia. [Plant communities of Slovakia 2. Synantrophic vegetation] Bratislava, Veda

Jarolímek I, Banásová V, Ot’ahelová H (1999) Effects of ecological gradients on the vegetation zonation of the emergent bank. Biologia 54: 405-413

Jasprica N, Milović M, Dolina K, Lasić A. (2017) Analyses of the flora of railway stations in the Mediterranean and sub-Mediterranean areas of Croatia and Bosnia and Herzegovina. Nat Croat 26(2):271-303. https://doi.org/10.20302/NC.2017.26.21

Jehlík V, Zaliberová M, Májeková J (2017) The influence of the eastern migration route on the Slovak flora - a comparison after 40 years. Tuexenia 37:313-332

Jurko A (1964) Feldheckengesellschaften und Uferweidengebüsche des Westkarpatengebietes. Biol Práce 10(6):5-102

Jurkovič M (1970) Vzácny ovocinársko-záhradnícky rukopis z roku 1672 [Rare fruit grower- gardener manuscript from 1672]. In: Mesároš Š (ed) Slovenské ovocinársto kedysi a dnes. Bratislava, pp 7-9

Kautmanová I, Brachtýr O, Gbúrová Štubňová E, Szabóová D, Šottník P, Lalinská-Voleková B (2021) Potentially toxic elements in macromycetes and plants from areas affected by antimony mining. Biologia 76(7)

Kliment J, Hrivnák R, Slezák M, Blanár D, Jarolímek I (2021) Classification of common hazel scrub vegetation in Slovakia. Biologia 76(7)

Kliment J, Valachovič M (eds) (2007) Rastlinné spoločenstvá Slovenska. 4. Vysokohorská vegetácia. [Plant communities of Slovakia 4 High-mountain vegetation] Bratislava. Veda

Kochjarová J, Hrivnák R, Letz DR (2015) Flóra a vegetácia na obnaženom dne vypustených vodných nádrží v okolí Zvolena a Banskej Štiavnice [Flora and vegetation on the bare bottom of drained water reservoirs around Zvolen and Banská Štiavnica]. Bull Slov Bot Spoločn 37/1 87-102

Kompała-Bąba A, Bierza W, Błońska A, Sierka E, Magurno F, Chmura D, Besenyei L, Radosz Ł, Woźniak G (2019) Vegetation diversity on coal mine spoil heaps - how important is the texture of the soil substrate? Biologia 74(4):419-436. https://doi.org/10.2478/s11756019-00218-x

Konečný P (2012) 250. výročie Banskej a lesníckej akadémie v Banskej Štiavnici : Jej význam pre vývoj montánneho školstva v RakúskoUhorsku, 1762-1919 [250th anniversary of the Mining and Forestry Academy in Banská Štiavnica: Its significance for the development of mountain education in Austria-Hungary, 1762-1919]. Tibor Turčan \& Banská agentúra, Košice

Kontriš J (1981) Pôdneekologické a fytocenologické pomery lužných lesov Liptovskej kotliny [Soil ecological and phytosociological 
conditions of floodplain forests of the Liptovská kotlina Basin]. Biol Práce 27(3):1-166

Kormut'ák A (1981) Isozyme composition of some Abies species. Biologia 36:3-13

Kormuták A, Benčat' F, Rudin D, Seyedyazdani R (1982) Isoenzyme variation in the four Slovakian populations of Abies alba mill. Biologia 37:433-440

Kormuták A, Ostrolucká M, Vooková B, Pret’ová A, Fecková M (2005) Artificial hybridization of Pinus sylvestris L. and Pinus mugo Turra. Acta Biol Cracov Ser Bot 47:129-134

Kormuták A, Demanková B, Gömöry D (2008) Spontaneous hybridization between Pinus sylvestris L. and Pinus mugo Turra in Slovakia. Silvae Genet 57:76-82. https://doi.org/10.1515/sg-2008-0012

Kšiňan S, Duurišová L', Eliáš P. Jr. (2021) Genome size estimation of Cotoneaster species (Rosaceae) from the Western Carpathians. Biologia 76(7)

Kubinská A, Janovicová K, Šoltés R (2001a) Red list of bryophytes of Slovakia (December 2001). In: Baláž D et al (eds) Červený zoznam rastlín a živočíchov Slovenska. Ochr Prír 20:48-81

Kubinská A, Janovicová K, Šoltés R (2001b) Updated checklist of liverworts, hornworts and mosses of Slovakia. Bryonora Praha 28:4-10

Kučera V, Valda S, Fedosova AG (2021) New records of earth tongue Leucoglossum leucosporum in Central Europe. Biologia 76(7)

Letz DR (2016) Kňaz a botanik Ján Futák - chronológia života a diela [Priest and botanist Ján Futák - chronology of life and work]. Bull Slov Bot Spoločn 38(Suppl. 3):5-41

Longauer R, Gömöry D, Paule L, Karnosky DF, Maňkovská B, MüllerStarck G, Percy K, Szaro R (2001) Selection effects of air pollution to gene pools of Norway spruce, European silver fir and European beech. Environ Pollut 115:405-411. https://doi.org/10. 1016/s0269-7491(01)00230-5

Lumnitzer S (1791) Flora Posoniensis exhibens circa Posonium sponte crescentes secundum systema sexuale Linneanum. viii $+557 \mathrm{p}$, Lipsiae

Macková L, Vít P, Ďurišová L, Eliáš P Jr, Urfus T (2017) Hybridization success is largely limited to homoploid Prunus hybrids: a multidisciplinary approach. Plant Syst Evol 303:481-495. https://doi.org/10. 1007/s00606-016-1385-4

Májeková J, Letz DR, Slezák M, Zaliberová M, Hrivnák R (2014) Rare and threatened vascular plants of the railways in Slovakia. Biodiv Res Conserv 35(1):75-85

Májeková J, Zaliberová M, Andrik EJ, Protopopova VV, Shevera MV, Ikhardt P (2021) A comparison of the flora of the chop (Ukraine) and Čierna nad Tisou (Slovakia) border railway stations. Biologia 76(7)

Mártonfiová L, Dudáš M, Mártonfi P (2021) Herbarium of botanical garden of Pavol Jozef Šafárik University in Košice - a part of the botanical history of the region of eastern Slovakia. Thaiszia - J Bot 31 (in press)

McKinnon KM (2018) Flow cytometry: an overview. Curr Protoc Immunol 120:5.1.1-5.1.11. https://doi.org/10.1002/cpim.40

Mišíková K, Godovičová K, Šoltés R, Širka P (2020) Checklist and red list of mosses (Bryophyta) of Slovakia. Biologia 75(1):21-37. https://doi.org/10.2478/s11756-019-00349-1

Mišíková K, Godovičová K, Širka P, Šoltés R (2021) Checklist and red list of hornworts (Anthocerotophyta) and liverworts (Marchantiophyta) of Slovakia. Biologia 76(7)

Mucina L, Bültmann H, Dierßen K et al (2016) Vegetation of Europe: hierarchical floristic classification system of vascular plant, bryophyte, lichen, and algal communities. Appl Veg Sci 19:3-264. https://doi.org/10.1111/avsc. 12257

Nosalj S, Šimonovičová A, Pauditšová E, Hanajík P, Vojtková H, Benková M (2021) Diversity of soil microscopic filamentous fungi in dystric Cambisol at the Banská Štiavnica - Šobov (Slovakia) locality after application of remediation measures. Biologia 76(7)
Novinska R, Czarna A (2008) Impact of Railway Facility Operation on Floral Growth in Powodowo, the Region of Wielkopolska. Polish J of Environ Stud 17:613-622

Palaj A, Kollár J (2021) Expansion of phanerophytes above the timberline in the Western Carpathians Biologia 76(7)

Passarge H (1979) Über montane Rhamno-Prunetea im Unterharz. Phytocoenologia 6:352-387. https://doi.org/10.1127/phyto/6

Plóciennik M, Kruk A, Forysiak J, Pawlowski D, Mianowicz K, Elias S, Borowka RK, Kloss M, Obremska M, Coope R, Krapiec M, Kittel P, Zurek S (2015) Fen ecosystem responses to water-level fluctuations during the early and middle Holocene in Central Europe: a case study from Wilczków, Poland. Boreas 44:721-740. https://doi.org/ 10.1111/bor.12129

Procházka J, Pišút P, Horáčková Š, Kapustová V (2021) Holocene regression of the critically endangered species Cladium mariscus (L.) Pohl on Žitný Ostrov Island (site Mad, Danubian plain lowland). Biologia 76(7)

Pulišová K, Skokanová K, Šingliarová B, Kochjarová J (2021) Karyological and morphological differentiation of the Tanacetum corymbosum group (Asteraceae) in the Slovak part of the Carpathians. Biologia 76(7)

Račko M, Ozdín D, Kučerová G, Jurkovič L', Vaculík M (2021) Occurrence and uptake of heavy metals by selected terrestrial orchids in extreme conditions of initial soils on previous mining sites. Biologia 76(7)

Reuss G (1853) Května Slovenska čili opis všech jevnosnubných na Slovensku divorastaucích a mnohých zahradních zrostlin podlé saustavy De Candolle-ovy [Flora of Slovakia or a description of all wild-growing and many garden plants in Slovakia according to the De Candolle system]. Lorber, Banská Štávnica

Richert E, Achtziger R, Dajdok Z, Günther A, Heilmeier H, Hübner A, John H, Šumberová K (2016) Rare wetland grass Coleanthus subtilis in central and Western Europe - current distribution, habitat types, and threats. Acta Soc Bot Pol 85:3511. https://doi.org/10. 5586/asbp.3511

Sun H, Wang J, Xiong J, Bian J, Jin H, Cheng W, Li A (2021) Vegetation change and its response to climate change in Yunnan Province. China Advances in Meteorology. https://doi.org/10.1155/2021/ 8857589

Šumberová K, Hrivnák R (2013) Formalised classification of the annual herb vegetation of wetlands (Isoëto-Nano-Juncetea class) in the Czech Republic and Slovakia (Central Europe). Phytocoenologia 43:13-40

Theocharopoulos M, Georgiadis T, Dimitrellos G, Chochliouros S, Tiniakou A (2006) Vegetation types with Cladium mariscus (Cyperaceae) in Greece. Willdenowia 36:247-256. https://doi.org/ 10.3372/wi.36.36120

Turis P, Kliment J, Feráková V, Dítě D, Eliáš P, Hrivnák R, Koštál J, Šuvada R, Mráz P, Bernátová D (2014) Red list of vascular plants of the Carpathian part of Slovakia. Thaiszia - J Bot 24(1):35-87

Ujházyová M, Ujházy K, Máliš F, Slezák M, Hrivnák R (2021) Syntaxonomical revision of the order Fagetalia sylvaticae Pawłowski ex Pawłowski et al. 1928 in Slovakia. Biologia 76(7)

Vanneste T, Michelsen O, Graae BJ, Kyrkjeeide MO, Holien H, Hassel K, Lindmo S, Kapas RE, De Frenne P (2017) Impact of climate change on alpine vegetation of mountain summits in Norway. Ecol Res 32:579-593. https://doi.org/10.1007/s11284-017-1472-1

Valachovič M (ed) (2001) Rastlinné spoločenstvá Slovenska. 3. Vegetácia mokradí. [Plant communities of Slovakia 3 - Wetland vegetation] Bratislava, Veda

Valachovič M (ed) (1995) Rastlinné spoločenstvá Slovenska. 1. Pionierska vegetácia. [Plant communities of Slovakia 1 - Pioneer vegetation] Bratislava, Veda

Vinogradova YK, Bochkin VD, Mayorov SR, Teplov K, Barinov AV (2017) Historical flora of Moscow's railway junction (until 2012). 
Hortus Bot 12:88-136. http://hb.karelia.ru/journal/atricle.php?id= 3402. https://doi.org/10.15393/j4.art.2017.3402

Vozárová M (1996) Herbár pátra Cypriana [Herbarium of father Cyprian]. Pamiatky a múzeá 1996(3):42-45

Willner W (2002) Syntaxonomische revision der südmitteleuropäischen Buchenwälder Syntaxonomical revision of the beech forests of southern Central Europe. Phytocoenologia 32(3):337-453. Https:// doi.org/10.1127/0340-269X/2002/0032-0337

Willner W, Grabherr G (eds) (2007) Die Wälder und Gebüsche Österreichs. Ein Bestimmungswerk mit Tabellen. Spektrum Akademischer Verlag, Heidelberg

Willner W, Jiménez-Alfaro B, Agrillo E, Biurrun I, Campos JA, Čarni A, Casella L, Csiky J, Ćušterevska R, Didukh YP, Ewald J, Jandt U, Jansen F, Kącki Z, Kavgacı A, Lenoir J, Marinšek A, Onyshchenko V, Rodwell JS, Schaminée JH, Šibík J, Škvorc Ž, Svenning JC, Tsiripidis I, Turtureanu PD, Tzonev R, Vassilev K, Venanzoni R, Wohlgemuth T, Chytrý M (2017) Classification of European beech forests: a Gordian Knot? Appl Veg Sci 20(3):494-512. https://doi. org/10.1111/avsc. 12299

Woch MW (2017) Species trait-environment relationships in semi-dry Brachypodium pinnatum grasslands on old waste heaps left by $\mathrm{Zn}$ -
$\mathrm{Pb}$ mining in the western Małopolska region (S Poland). Tuexenia $37: 247-270$

Woch MW (2018) Factors of variation in beech forest understory communitieson waste heaps left by historical $\mathrm{Zn}-\mathrm{Pb}$ ore mining. Ecotoxicol Environ Saf 164:681-689. https://doi.org/10.1016/j. ecoenv.2018.08.067

Woch MW, Kapusta P, Stefanowicz AM (2016) Variation in dry grasland communities along a heavy metals gradient. Ecotoxicology 25:80 90. https://doi.org/10.1007/s10646-015-1569-7

Woch MW, Radwańska M, Stanek M, Łopata B, Stefanowicz AM (2018) Relationships between waste physicochemical properties, microbialactivity and vegetation at coal ash and sludge disposal sites. Sci Total Environ 642:264-275. https://doi.org/10.1016/j. scitotenv.2018.06.038

Žabka M, Ďurišová L', Eliáš P Jr, Baranec T (2018) Genome size and ploidy level among wild and cultivated Prunus taxa in Slovakia. Biologia 73:121-128. https://doi.org/10.2478/s11756-018-0014-9

Publisher's note Springer Nature remains neutral with regard to jurisdictional claims in published maps and institutional affiliations. 